\title{
Perfusion imaging INSPIREs precision medicine in stroke
}

Keith W. Muir, MD, and Bernard Yan, DMedSci

Neurology ${ }^{\circledR}$ 2019;92:1075-1076. doi:10.1212/WNL.0000000000007554

Stroke is a clinical syndrome with diverse causes and mechanisms. Historically, reliance on clinical diagnosis and exclusion of intracerebral hemorrhage and other nonstroke structural pathologies by $\mathrm{CT}$ alone has produced highly heterogeneous trial populations; as a result, any treatment effect has likely been obscured by the random noise of the many patients in whom no relevant biological target exists, a strategy that greatly inflates sample sizes. ${ }^{1}$ Advances in brain and vascular imaging have driven the recent wave of positive clinical trials investigating reperfusion therapies in acute ischemic stroke, allowing the identification of patients with relevant therapeutic targets, such as intracranial large artery occlusion, clinically meaningful volumes of potentially reversible tissue hypoperfusion (the ischemic penumbra), and small volumes of irreversible tissue damage (the ischemic core). Combinations of angiographic and perfusion imaging, primarily using $\mathrm{CT}$, allow pathophysiologic characterization of patients. The adoption of rigorous imaging selection in clinical trials based on the concept of treatment-related acute imaging targets $^{2}$ has allowed treatment effects to be demonstrated with achievable sample sizes, and validates the precision medicine concept in acute stroke. ${ }^{3}$

Further information to inform future clinical trial design is presented in this issue of Neurology ${ }^{\circledR}$ by Tian et al. ${ }^{4}$ on behalf of the International Stroke Perfusion Imaging Registry (INSPIRE). The publication details CT perfusion findings, intracranial vessel occlusion site, and clinical outcomes in a much broader range of acute stroke patients than that which participated in recent clinical trials.

The analysis is motivated by the changing landscape and needs for clinical trials. Recent endovascular thrombectomy trials have included predominantly patients with occlusion of the first segment of the middle cerebral artery (MCA) or the intracranial internal carotid artery, ${ }^{5}$ and in many countries this now constitutes the standard of care for such patients. Future trials in these patients face the challenge of demonstrating additive treatment effect on a background of continually advancing endovascular treatment. Clinical outcomes are well-characterized only in the subgroup of patients enrolled in recent trials, however, and the perfusion characteristics of trial participants predominantly reflect selection criteria that include clinical severity, CT features such as the Alberta Stroke Program Early CT Score (ASPECTS), and specific perfusion imaging requirements that only partially represent the clinical spectrum presenting to hospitals. More distal occlusions, or those in other vascular territories such as the posterior cerebral artery, will likely constitute an important target population for future trials, particularly for thrombolytic trials, and data on outcomes related to these non-thrombectomy populations-which constituted more than one third of the INSPIRE population-are valuable. Distal MCA occlusions and posterior circulation events may have substantial neurologic deficit and are commonly disabling, and these data from INSPIRE may also inform clinical decisions pending further randomized trial data, since advances in endovascular treatment make such sites increasingly amenable to intervention.

\author{
Correspondence \\ Dr. Muir \\ Keith.Muir@glasgow.ac.uk
}

\section{RELATED ARTICLE}

Influence of occlusion site and baseline ischemic core on outcome in patients with ischemic stroke

Page 1083

From the Institute of Neuroscience \& Psychology (K.W.M.), University of Glasgow, Queen Elizabeth University Hospital, UK; and Neurointervention Service (B.Y.), Melbourne Brain Centre, Royal Melbourne Hospital, University of Melbourne, Parkville, Australia.

Go to Neurology.org/N for full disclosures. Funding information and disclosures deemed relevant by the authors, if any, are provided at the end of the editorial. 
Biomarkers may be of utility in phase 2 clinical trials where conventional 90 -day disability outcomes may be of limited value due to small sample size. The INSPIRE investigators present data on imaging indices such as infarct volume, penumbral salvage, reperfusion, and recanalization that may offer greater power than clinical measures.

Registry data have inherent limitations that should be borne in mind. Information on the treatment effect of IV thrombolysis as presented in the article must be regarded with particular caution. Routinely captured factors such as stroke severity and patient age may explain treatment decisions to only a limited extent, particularly in less severe cases, ${ }^{6}$ and investigators had access to angiographic and perfusion data, which are interpreted differently by different physicians. ${ }^{7}$ The central processing of perfusion data using a common platform is appropriate in a study, but such uniformity may be more challenging to achieve in future trials. Different software platforms may yield different findings. Patients were selected if within a conventional time window for IV thrombolysis ( $<4.5$ hours from onset) with alteplase, but longer time windows are of increasing interest as data accrue for late window thrombolysis, and the thrombolytic agent of choice may change if promising trials of tenecteplase lead to change in clinical practice. ${ }^{8-10}$ Nonetheless, INSPIRE provides data that will inform future clinical trial design in the acute stroke field.

\section{Study funding}

No targeted funding reported.

\section{Disclosure}

Dr. Muir has served on advisory boards for Bayer, Boehringer Ingelheim, Daiichi Sankyo, and ReNeuron and has received trial support from Boehringer Ingelheim, Medtronic, and Codman. Dr. Yan reports no disclosures. Go to Neurology. org $/ \mathrm{N}$ for full disclosures.

\section{References}

1. Muir KW. Heterogeneity of stroke pathophysiology and neuroprotective clinical trial design. Stroke 2002;33:1545-1550.

2. Warach SJ, Luby M, Albers GW, et al. Acute stroke imaging research roadmap III: imaging selection and outcomes in acute stroke reperfusion clinical trials: consensus recommendations and further research priorities. Stroke 2016;47:1389-1398.

3. Hinman JD, Rost NS, Leung TW, et al. Principles of precision medicine in stroke. J Neurol Neurosurg Psychiatry 2017;88:54-61.

4. Tian H, Parsons MW, Levi CR, et al. Influence of occlusion site and baseline ischemic core on outcome in patients with ischemic stroke. Neurology 2019;92:e2626-e2643.

5. Goyal M, Menon BK, van Zwam WH, et al. Endovascular thrombectomy after largevessel ischaemic stroke: a meta-analysis of individual patient data from five randomised trials. Lancet 2016;387:1723-1731.

6. Levine SR, Weingast SZ, Weedon J, et al. To treat or not to treat? Stroke 2018;49: 1933-1938.

7. Bivard A, Levi C, Krishnamurthy V, et al. Perfusion computed tomography to assist decision making for stroke thrombolysis. Brain 2015;138:1919-1931.

8. Parsons MW, Spratt N, Bivard A, et al. A randomised trial of tenecteplase versus alteplase for acute ischaemic stroke. New Engl J Med 2012;366:1099-1107.

9. Huang XY, Cheripelli BK, Lloyd SM, et al. Alteplase versus tenecteplase for thrombolysis after ischaemic stroke (ATTEST): a phase 2, randomised, open-label, blinded endpoint study. Lancet Neurol 2015;14:368-376.

10. Campbell BCV, Mitchell PJ, Churilov L, et al. Tenecteplase versus alteplase before thrombectomy for ischemic stroke. N Engl J Med 2018;378:1573-1582. 


\section{Neurology}

\section{Perfusion imaging INSPIREs precision medicine in stroke Keith W. Muir and Bernard Yan}

Neurology 2019;92;1075-1076 Published Online before print May 1, 2019

DOI 10.1212/WNL.0000000000007554

This information is current as of May 1, 2019

$\begin{array}{ll}\begin{array}{l}\text { Updated Information \& } \\ \text { Services }\end{array} & \begin{array}{l}\text { including high resolution figures, can be found at: } \\ \text { http://n.neurology.org/content/92/23/1075.full }\end{array} \\ \text { References } & \text { This article cites } 10 \text { articles, } 4 \text { of which you can access for free at: } \\ & \text { http://n.neurology.org/content/92/23/1075.full\#ref-list-1 } \\ \text { Subspecialty Collections } & \text { This article, along with others on similar topics, appears in the } \\ & \text { following collection(s): } \\ & \text { CT } \\ & \text { http://n.neurology.org/cgi/collection/ct } \\ & \text { DWI } \\ \text { http://n.neurology.org/cgi/collection/dwi } & \text { Infarction } \\ & \text { http://n.neurology.org/cgi/collection/infarction } \\ & \text { Information about reproducing this article in parts (figures,tables) or in } \\ & \text { its entirety can be found online at: } \\ & \text { http://www.neurology.org/about/about_the_journal\#permissions } \\ \text { Permissions \& Licensing } & \text { Information about ordering reprints can be found online: } \\ & \text { http://n.neurology.org/subscribers/advertise }\end{array}$

Neurology ${ }^{\circledR}$ is the official journal of the American Academy of Neurology. Published continuously since 1951, it is now a weekly with 48 issues per year. Copyright @ 2019 American Academy of Neurology. All rights reserved. Print ISSN: 0028-3878. Online ISSN: 1526-632X.

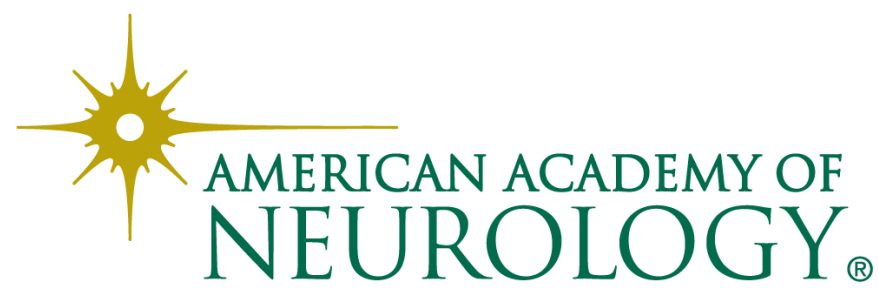

